\title{
KOMISI KEPOLISIAN DALAM PERBANDINGAN
}

\author{
Edi Saputra Hasibuan
}

Fakultas Hukum, Universitas Bhayangkara Jakarta Raya

hedihasibuan@yahoo.co.id

\begin{tabular}{|c|c|c|}
\hline Naskah diterima: & Revisi: & Naskah disetujui: \\
$26 / 09 / 2019$ & $2 / 10 / 2019$ & $7 / 10 / 2019$ \\
\hline
\end{tabular}

\begin{abstract}
Abstrak
Peran dan tanggung jawab Polisi sebagai penegak hukum tentunya sangat diandalkan, dan tentunya sangat diharapkan implementasinya demi keadilan dan kemanfataan bagi masyarakat. Dalam prakteknya tentu Kepolisian mempunyai berbagai sistem dan standar operasional dalam menjalankan tugasnya, mulai dari sistem keamanan, sistem penyidikan, maupun sistem dalam menangani keluhan dan kritikan dari masyarakat. Melihat pentingnya peran Kepolisian, maka tentunya bukan hanya Indonesia yang memiliki "penegak hukum", Negara lain pun tentunya memiliki Polisi mereka sendiri. Dalam tulisan kali ini, Amerika dan Kanada menjadi contoh Negara yang juga mempunyai "Penegak Hukum". Perbandingan ini tentunya bukan untuk mencari Negara mana yang lebih baik dalam sistem dan penanganan masalahnya, namun untuk melihat dan mempelajari cara kerja dari sistem mereka. Mengambil hal yang positif dan mengesampingkan yang tidak perlu. Bagaimana kemudian Polisi Indonesia dapat berkembang semakin maju dengan belajar dari Negaranegara tetangga.
\end{abstract}

Kata kunci: Polisi, Perbandingan, Amerika, Kanada, Sistem

\begin{abstract}
The role and responsibility of the police as law enforcers is very reliable, and it is expected that its implementation is for the sake of justice and benefit the community. In practice, the Police has a variety of systems and operational standards in carrying out their duties, ranging from security systems, investigation systems, as well as systems in saving security and criticism from the public. Seeing the importance of the role of the Police, then not only Indonesia has "law enforcement", other countries also have the responsibility as their own police. In this article, America and Canada are examples of countries that also have "Law Enforcement". This comparison is not to look for which country is better in the system and maintenance, but to see and try the workings of their system. Choose the positive and put aside unnecessary. How will the Indonesian Police be able to advance by learning from neighboring countries.
\end{abstract}

Keywords: Police, Comparison, America, Canada, System 


\section{Pendahuluan}

Motto dari Polisi berbunyi Rastra Sewakottama yang berasal dari bahas sansekerta dengan arti pelayan utama bangsa. Selanjutnya polisi adalah alat Negara yang memiliki tugas untuk menjaga dan memlihara keamanan di masyarakat, tak lupa dengan sloganya "Polisi Mengayomi, Melindungi dan Melayani Masyarakat". Sebagaimana sebuah alat, polisi menjadi perpanjangan tangan dari implementasi sebuah aturan Negara yang dilanggar oleh masyarakat. Selain itu, Indonesia merupakan Negara hukum ${ }^{1}$ (recht staat). Dalam pemaknaan ini dimaksudkan adalah adalah negara yang menegakkan supremasi hukum untuk mewujudkan kebenaran dan keadilan, dimana didalamnya tidak ada kekuasaan yang tidak dapat dipertanggungjawabkan.

Sejak runtuhnya orde baru dan mundurnya mantan presiden ke 2 yaitu Soeharto dan digantikan wakilnya BJ Habiebie, mengindikasikan lahirnya reformasi pada tahun 1998, dan di kala itu lah yang mana sebelumnya kedudukan dari polisi di pisahkan dari ABRI. Pada masa orde baru, polisi masuk dalam Dwi Fungsi ABRI bersama dengan Militer. Berlandaskan dengan konstitusional dengan berlakunya kembali UUD $1945 \mathrm{kala}^{\mathrm{itu}}{ }^{2}$. Namun kembali setelah bergantinya orde baru sistem Dwi Fungsi ini kian lama terhapuskan. Pemisahan antara polisi dan militer dituntaskan oleh lahirmya Ketetapan MPR nomor VI/MPR/2000 tentang pemisahan TNI dan Polri.

Di Negara demokratis ini, Indonesia memilih sistem Centralized system of policing atau sistem kepolisian terpusat (Sentralisasi) yang berartikan kewenangan kepolisian diambil langsung oleh pemerintah nasional / pusat. Segala kebijakan dan pengambilan keputusan strategi berada dibawah kendali dan pengawasan langsung oleh Pemerintah. Hal ini ter-realisasikan dari keluarnya PerKap (Peraturan Kapolri), yang berlaku untuk seluruh polisi di Indonesia. Akan tetapi yang di takutkan dari sistem ini bisa membuat penyalahgunaan kekuatan polisi oleh pemerintah.

Kepolisian adalah Negara Republik Indonesia adalah alat negara yang berperan dalam memelihara keamanan ${ }^{3}$. Pengertian keamanan memang pada umumnya erat dengan kaitannya dengan polisi. Pandangan mengenai keamanan dalam Tata Tentram Karta Raharja dimana di jelaskan arti bahwa "Aman" mengandung empat unsur yang fundamental, sebagai berikut:

\footnotetext{
${ }^{1}$ Pasal 1 ayat (3) UUD 1945

${ }^{2}$ Seoebijono, DWIFUNGSI ABRI, Yogyakarta, Gadjah Mada University Press, 1995, hal 48

${ }^{3}$ Pasal 2 ayat (2) lahirmya Ketetapan MPR nomor VI/MPR/2000
} 
1. Security, adalah perasaan bebas dari gangguan baik fisik maupun psikis.

2. Surety, adalah perasaan bebas dari kekhawatiran.

3. Safety, adalah perasaan bebas dari resiko.

4. Peace, adalah perasasaan damai lahiiriah dan bathiniah ${ }^{4}$.

Pada tahun 2002 lahirlah undang - undang yang khusus mengenai Kepolisian Negara, UU NO 2 Tahun 2002 Tentang Kepolisan Negera Republik Indonesia. Berlakunya UU ini menjelaskan fungsi, tugas dan kewenangan dari kepolisian. Selaras dengan pasal 2:" Fungsi Kepolisian adalah salah satu fungsi pemerintahan Negara di bidang pemelihara keamanan dan ketertiban masyarakat, penegak hukum, perlindungan, pengayoman dan pelayanan masyarakat".

Sedangkan Pasal 3: “(1) Pengemban fungsi Kepolisian adalah Kepolisian Negara Republik Indonesia yang dibantu oleh: a. kepolisian khusus, b. pegawai negri sipil dan/atau c. bentuk-bentuk pengamanan swakarsa. (2) Pengemban fungsi Kepolisian sebagaimana dimaksud dalam ayat (1) huruf a, b, dan c, melaksanakan fungsi Kepolisian sesuai dengan peraturan perundang-undangan yang menjadi dasar hukum masing-masing.

Beralih ke Tugas pokok adalah Kepolisian Pasal 13: Tugas Pokok Kepolisian Negara Rrepublik Indonesia dalam UU No.2 tahun 20002 adalah sebagai berikut: 16 1. Memelihara keamanan dan ketertiban masyarakat 2. Menegakkan hukum 3. Memberikan perlindungan, pengayoman dan pelayanan kepada masyarakat. “, penjabaran tugas Kepolisian di jelaskan lagi apada Pasal 14 UU Kepolisian RI.

Sedangkan Kewenangan Polisi tertulis pada pasal 15 (1): a. menerima laporan dan/atau pengaduan; b. membantu menyelesaikan perselisihan warga masyarakat yang dapat mengganggu ketertiban umum; c. mencegah dan menanggulangi tumbuhnya penyakit masyarakat; d. mengawasi aliran yang dapat menimbulkan perpecahan atau mengancam persatuan dan kesatuan bangsa; dan seterusnya. Pada ayat (2) wewenang dari Kepolisian diberikan dari peraturan perundang - undangan lainya antara lain : a. memberikan izin dan mengawasi kegiatan keramaian umum dan kegiatan masyarakat lainnya; $b$. menyelenggarakan registrasi dan identifikasi kendaraan bermotor; c. memberikan surat izin mengemudi kendaraan bermotor; d. menerima pemberitahuan tentang kegiatan politik; e. memberikan izin dan melakukan pengawasan senjata api, bahan peledak, dan senjata tajam;dst.

\footnotetext{
${ }^{4}$ Kelana Momo, Konsep - konsep Hukum Kepolisian Indonesia, Jakarta, PTIK”Press”,2007, hal 15.
} 
Kepolisian dalam menjalankan tugasnya tidak serta merta sendirian saja, melainkan mendapati pengawasan yang dilakukan oleh KOMPOLNAS atau Komisi Kepolisian Nasional yang mana hal ini Kompolnas adalah suatu lembaga independen. Posisi dari komisi ini berada di bawah Presiden ${ }^{5}$, selain dengan adanya pengawasan, Kompolnas hadir untuk trasnparasi dan akuntabilitas dari Kepolisian. Dalam berdirinya Kompolnas ini, di cita citakan menjadi lembaga yang obyektif dan konsisten untuk memperhatikan kebijakan yang dicetuskan oleh presiden kepada kinerja dan tugas pokok dari polisi.

Upaya Kompolnas Dalam mendinamisir pencapaian kondisi POLRI yang professional, Mandiri, Berwibawa dan Dicintai Rakyat dengan dasar penugasan Kompolnas ada pada Ketetapan MPR NO. VII/2000 Pasal 8, yang berisikan lembaga kepolisian membantu presiden menentukan arah kebijakan polri, dengan melakukan menerima keluhan masukan masyarakat pada kinerja polisi ${ }^{6}$. Jabaran lanjutan dari MPR NO. VII/2000 adalah lahirnya UU NO 2 Tahun 2002 Tentang Kepolisan Negera Republik Indonesia. Tertulis dalam BAB VI, Kompolnas diberikan atribusi untuk membuat anggaran belanja POLRI ${ }^{7}$, dengan beberapa pertanyaan antara lain seberapa besar anggaran yang dibutuhkan Polri dan darimana sumber anggaran yang diambil, serta sepertiapa komposisi dari pengadaan dana tersebut.

Hadirnya Kompolnas ini lahir karna keputusan presiden, yakni pada Peraturan Presiden Republik Indonesia Nomor 17 Tahun 2005 Tentang Komisi Kepolisian Nasional. Serta untuk pengangkatan dan pemberhantian dilakukan oleh Presiden. Kedekatan Presiden dan Kompolnas juga tergambar jelas dalam tugas yang di emban oleh Kompolnas yaitu (a) membantu Presiden dalam menetapkan arah kebijakan Kepolisian Negara Republik Indonesia; dan (b) memberikan pertimbangan kepada Presiden dalam pengangkatan dan pemberhentian Kepala Kepolisian Negara Republik Indonesia. Di atur dalam pasal 3 karna keputusan presiden, yakni pada Peraturan Presiden Republik Indonesia Nomor 17 Tahun 2005 Tentang Komisi Kepolisian Nasional. Selain dengan kedekatan dalam tugas Kompolnas sendiri bertanggung jawab pada Presiden langsung dalam menjalankan tugasnya.

Selanjutnya dalam wewenang Kompolnas tercantum pada pasal 4: (a) mengumpulkan dan menganalisis data sebagai bahan pemberian saran kepada Presiden yang berkaitan dengan anggaran Kepolisian Negara Republik Indonesia, pengembangan sumber

\footnotetext{
${ }^{5}$ Pasal 37 ayat (1) Undang - undang Nomor 2 Tahun 2002 Tentang Kepolisian Negara Indonesia.

${ }^{6}$ Op-cit, hal. 285

${ }^{7} \mathrm{Ibid}$, hal. 286
} 
daya manusia Kepolisian Negara Republik Indonesia, dan pengembangan sarana dan prasarana Kepolisian Negara Republik Indonesia. Seperti melakukan survey atas kepuasan masyarakat pada kinerja polisi di suatu daerah. (b) memberikan saran dan pertimbangan lain kepada Presiden dalam upaya mewujudkan Kepolisian Negara Republik Indonesia yang profesional dan mandiri; dan (c) menerima saran dan keluhan dari masyarakat mengenai kinerja kepolisian dan menyampaikannya kepada Presiden.

Hal yang dapat dilakukan oleh Kompolnas dalam mendinamisir Polri antara lain adalah melakukan pemantuan dari kinerja polisi dengan cara, membuka pusat pengaduan masalah dari masyarakat, cara ini dilayani oleh polres dan nantinya akan diserahkan kepada sekertarian Kompolnas atau dengan pilihan lain menyampaikan keluh kesah kepada website dan layanan email dan Front Office pada situs internet dan PO BOX Kompolnas untuk menerima laporan serta dapat dijangkau dengan layanan telpon Hotline Kompolnas. Demi melahirkan fungsi dari polisi yang optimal, Kompolnas dapat melakukan pemantauan dalam Platform media sosial, yang mana kita ketahui media sosial saat ini menjadi kebutuhan pokok masyarakat, atau Kompolnas melakukan diskusi kepada NGO/ LSM yang mempunyai bukti dan menunjang pengoptimalan kinerja polisi.

Kompolnas yang sangat diharapkan bisa dapat memperbaiki kinerja dari polri, tidaklah dengan demikian membuat menjadi suatu badan yang eksklusif yang tidak mendapat kritik atau sentuhand dari luar, maka dengan itu Kompolnas dapat terpantau oleh masyarakat luas dan juga mungkin untuk dikoreksi ${ }^{8}$.

\section{Polisi Di Beberapa Negara}

\section{Amerika Serikat}

Amerika Serikat merdeka dari jajahan inggris saat itu, pada tanggal 4 juli 1776, hingga sampai saat ini diisi oleh 50 negara bagian. Amerika serikat menjadi salah satu Negara federal yang yang mana artinya, negera tersebut dihimpun oleh beberapa Negara bagian yang menjadi kesatuan dalam suatu Nation. Bagi setiap Negara bagian memeliki wewenang otonom untuk mengatur wilayahnya. Untuk penalaran dalam Indonesia, bisa di contohkan penempatanya seperti suatu provinsi. Satu perbedaan yang terlihat jelas lagi yaitu, jika Negara kesatuan peraturan setiap daerah terikat oleh Undang - undang dan pemerintah pusat bisa melakukan interversi kebijakan pusat ke daerah. Sedangkan di suatu Negara federal, merupakan kebalikan dari Negara kesatuan yaitu peraturan daerah tidak terikat dengan

\footnotetext{
${ }^{8}$ Ibid, hal. 298
} 
undang - undang, tidak bisa mengatur untuk keseluruhan wilayah dan hanya peraturan daerah lah yang mutlak.

Sebagai Negara demokratis Amerika Serikat memiliki sistem kepolisian yang fragmented system of policing atau sistem polisi yang datang dengan terpisah dan berdiri sendiri. Hal ini dikarenakan sistem desentralisasi dari wewenang kepolisian yang yuridiksinya hanya berlaku pada suatu daerah wilayahnya masing - masing, penawasan yang dilakukan pada sistem ini diawasi oleh pemerintahan daerah, serta departemen kepolisian daerah bertanggung jawab atas tuganya pada pemerintah daerah. Sistem ini lahir untuk mencegah terjadinya penyalahgunaan wewenang kepolisan oleh pemerintah pusat. Karena ada kekhawatiran itu lah sistem ini lahir dan dibentuk atas dasar ciri - ciri dari kesesuaian dari wilayah masing - masing.

Sejak 1945 kepolisian amerika memang sudah mengaplikasikan sistem desentralisasi, dimana di tahun itu ada Lima jenis agen kepolisian yang pada saat itu memiliki tugas yang khusus dan berbeda, dapat diidentifikasi: pertama, sistem federal yang meliputi petugas yang melekat pada Departemen Kehakiman (Biro Federal AS investigasi), hal ini nampak pada keberadaan dari polisi dalam sebuah persidangan di negara anglo saxon ini, dan yang kedua Biro Pendapatan Internal (mengkhususkan diri dalam pajak ), ketiga Dinas Rahasia Amerika Serikat atau biasanya dikenal dengan CIA (Central Intelligence Agency) merupakan agen khusus dari USA untuk mencari informasi yang dibutuhkan baik dari dalam negri sendiri atau informasi dari Negara lain atau musuh, selanjutnya keempat Penegakan Narkoba Administrasi atau DEA (Drug Enforcement Administration) merupakan kesatuan pemberantasan penyelundupan dan pembererdaran narkoba, yang dibentuk oleh persetujuan dari presiden USA saat itu Richard Nixon pada tahun 1972, jika di samakan di Indonesia DEA sama seperti BNN apa adanya, terakhir yang kelima Layanan Pemeriksaan Pos; pasukan polisi danagen investigasi kriminal yang dibentuk oleh masing-masing dari 50 negara, pasukan kepolisian yang dibentuk dan berada di daerah wilayah Negara bagian masing - masing. ${ }^{9}$

Ada 4 golongan jenjang dari hirarki kepolisian di Negara paman sam ini, yang pertama adalah Kepolisian Negara bagian, kedua Kepolisian Kota Besar, yang ketiga Kepolisian wilayah, dan yang terakhir adalah Kepolisian tugas Khusus.

\footnotetext{
${ }^{9}$ Brewer D. Jhon, dkk., The Police Public Order And The State, London, Macmillan press LTD, 1996, hlm. 110.
} 
Yang pertama sebagai kepolisian Negara bagian, mengemban tugas umum yang terjadi di daerah penempatan kepolisian tersebut, dalam tindakan polisi ini tidak jauh berbeda dari polisi lain yakni menegakkan hukum, melakukan penyidikan tindakan kriminal, tak luput juga dimaksudkan dengan menjalanlan tugas mengatur lalu - lintas di jalan raya dan menyediakan pelayanan teknologi dan ilmiah dan diizinkan juga membantu kasus membantu polisi lokal lain untuk kasus berat yang rumit yang mana wilayah juridiksinya antar distrik wilayah.

Di beberapa Kepolisian Negara bagian Pada biasanya Kepala kepolisian negara bagian disebut dengan chief, letaknya ada dibawak kegubernuran dari wilayah Negara bagian misalnya Kepolisian Negara Bagian Illinois (Illinois State Police). Sementara Negara Bagian Hawaii tidak menamakan lembaganya dengan police, melainkan dinas keselamatan umum, yang terdiri atas dua divisi: Sheriff dan Badan Pemberantasan Narkotika. Dari 50 negara bagian ada 22 menggunakan istilah state police, 18 mengunakan istilah highway patrol (misal, California yang sangat dikenal dalam film serial CHIPS), dan tujuh menggunakan istilah state patrol ${ }^{10}$.

Kedua kepolisian kota besar atau Municipal Police, berartikan sifat dan kaitanya tentu pada kota besar dan berkependudukan yang banyak maka dengan demikian membutuhkan jumlah personil yang banyak juga, karena pada dasarnya kedua hal tersebut nenjadi tolak ukur berbanding lurusnya dari banyaknya keperluan personil dari polisi. Contoh dari penamaan kota - kota besar adalah penggunaan nama dari Kepolisian Kota New York (NYPD) merupakan kepolisian lokal terbesar di AS yang diikuti Kepolisian Kota Chicago (CPD) sebagai terbesar yang kedua, kemudian disusul peringkat ketiga oleh Kepolisian Kota Los Angeles (LAPD).

Berikut yang ketiga Kepolisian Wilayah, kepala bagian dari Kepolisian Wilayah ini disebut dengan Sherrif dan bedanya dengan Kepolisian lain, Sherrif dipilih oleh rakyat yang bersangkutna dengan wilayah daerah tersebut, meskipun demikian seorang Sherrif dapat di berhentikan oleh seorang kepala daerah dengan alasan jika seorang Sherrif tersebut melanggar sebuah kode etik. Dari sini dapat dilihat perpaduan antara kuasa masyarakat dengan pemerintah daerah setempat. Meskipun demikian seorang Sherrif tetap melakukan tugasnya sebagai perpanjangan tangan dari pengaplikasian suatu aturan atau penegakan hukum, dan tak lupa juga memelihara keamanan masyarakat social.

\footnotetext{
${ }^{10}$ Diakses dari https://www.kompasiana.com/efrondp/54f8ffe7a33311fa608b464d/adakah-jabatan-sejeniskapolri-di-amerika-serikat. Pada 06 oktober 2019, jam 3:34 WIB
} 
Dan yang terakhir adalah Kepolisian tugas khusus, praktik dari Kepolisian tugas khusus ini adalah sebagai tambahan dari beberapa hal yang membutuhkan Improvement, seperti halnya polisi taman, yang tergambarkan pada salas satu adegan film di 21 Jumps Street. Tentu adanya polisi taman ini membantu dengan keadaan lingkungan masyarakat, yang seperti kita ketahui taman merupakan temapt yang umum dan banyak dilalui dan dihampiri oleh khalayak ramai, oleh karna itu butuh pengamanan yang optimal. Tidak luput hanya dari polisi taman saja, pertambahan bantuan tenaga polisi, berlaku juga untuk polisi badar udara, yang mana dalam hal ini polisi Bandar udara atau yag biasa di sebut dengan Marshall, memiliki tugas untuk melakukan pengaman dan menjadi alat pencium atas suatu hal yang mengindikasikan suatu masalah. Untuk melihat suatu contoh yang konkrit ada berapa adegan dalam film Non Stop, yang melakukan pencegahan ledakan bom di dalam sebuah pesawat. Penempatan dari Kepolisian tugas khusus ini tidak hanya dari dua hal diatas saja, akan tetapi penerapan dari hal ini kerap juga dilakukan pada polisi kampus, polisi pelabuhan, polisi penjaga kantor dan lain sebagainya. Pengankatan dan pemberhentian dari Polisi tugas khusu ini dilakukan oleh pemegang otoritas sesuai yuridiksi dari penempatan polisi tersebut, misalnya polisi kampus di tetapkan oleh rector, polisi pelabuhan oleh kepala pelabuhan dan lai sebagainya.

Dari berpraktiknya polisi di Amerika Serikat ini tentu memiliki kelebihan dan kekurangan, yakni kelebihannya adalah impelementasi dari sistem fragmented system of policing (sistem kepolisian yang terpisah atau berdiri sendiri) memiliki potensi untuk menyesuaikan dengan situasi keadaan masyarakat dari dimana polisi tersebut ditugaskan, hal ini lahir dari seorang Sheriff yang terpilih dari hasil voting masyarakat terhadap kesadaran kebutuhan pengamanan masyarakat. Karna dengan demikian maka keharmonisan antara Sheriff dan masyarakat memiliki ikatan yang di dasari keintiman yang lebih. Pengawasan terhadap kinerja polisi ini juga dilakukan oleh pemerintah daerah dan masyarakt itu sendiri juga.

Karena sifat kepolisian ini yang otonom dalam satu wilayah yuridiksinya, sehingga fokus dari polisi tersebut hanya terkonsentrasi saja pada satu objek. Sehingga polisi sudah memahami betul seperti apa budaya serta kebiasaan dari daerahnya masing - masing. Oleh karena itu kecil kemungkinan terjadi penyalahgunaan kekuasaan dan pemberlakuan dari adanya polisi, oleh pemerintah pusat, sepertinya saja pemerintah menginginkan polisi di tempat yang mana bukan seharusnya, yang membuat hal ini untuk keuntungan dari pemerintah pusat saja. Sehingga kontrol yang baik harus dilakukan oleh pemerintah daerah. 
Lebih pendek birokrasinya dalam pengusulan dana, karena langsung ditujukan kepada pemerintah daerah setempat.Hal ini terjadi dikarenakan lembaga Kepolisian dapat mengatur tugas Kepolisian baik secara adminstrasi maupun operasional secara otonom sesuai dengan peraturan perundang-undangan yang dikeluarkan oleh pemerintahan daerah setempat,sehingga masalah anggaran pun lembaga Kepolisian itu dapat mengajukan kepada pemerintahan daerah dimana lembaga Kepolisian itu berada,jadi tidak perlu sampai mengajukan anggaran kepada pemerintahan Pusat seperti hal nya Kepolisian pada sistem terpusat.

Selain kelebihannya maka tak lengkap tanpa adanya kekurangan, Kekurangan ini sendiri ada tidak lain karena pemberlakuan dari otonom kepolisian, seperti yang di jelaskan di atas setiap wilayah Negara bagian memiliki kewenangan untuk menjalankan keamanan daerah masing - masing melalui instansi kepolisian. Contoh kendala yang terjadi jika saja ada kasus tindak pidana yang melibatkan antara beberapa Negara bagian, hal ini akan menjadi sangat sulit untuk di selesaikan karna memiliki kewenangan wilayah masing - masing.

Akibat dari peraturan perundang-undangan masing-masing daerah, yang mana untuk Negara yang menganut sistem federal maka undang - undang Negara tidak mengikat kepada undang - undang derah, hal ini memicu munculnya dari kejahatan baru yang inofatif dari waktu - waktu hingga menimbulkan berbagai modus - modus operandi kejahatan yang beraneka ragam.

Patokan untuk penetapan standard profesionalisme sangat rabun di karenakan standart yang di berikan dari masing - masing pemerintah daerah, dalam hal ini akan sulit mengetahui standart yang tepat untuk lembaga - lembaga kepolisian daerah, di karenakan pemerintah daerah mendapati wewenang untuk membuat dan mengatur peraturan dan perundang undangannya sendiri, maka dengan ini lah membuat standart ke efektifan yang susah. Di tambah lagi dengan pemerintah pusat tidak bisa melakukan intervensi terhadap kepolisian daerah untuk mengatur fungsi operasional lembaga -lembaga kepolisian di daerah.

Karena pengawasan yang hanya dilakukan oleh pemerintah setempat, membuat pengawasan dari kepolisian menjadi kurang efisien, maka dengan itu di butuhkan pengawasan yang berlapis atau 2 pandangan atau lebih, untuk mengawasi kinerja polisi, mengingat tugas polisi yang sangat berat dan rentan terhadap segala hal yang berbau penyelewengan dan pembelotan atau korupsi dan lain sebagainya, yang di khawatirkan bagaimana jika pemerintah turut serta dalam pembelotan yang dilakukan kepolisian.

Dalam 10 amandemen pertama pada tahun 1791, konstitusi amerika serikat mengatur tentang kerangka hukum yang mengatur kepolisian dalam ketertiban umum, dalam kerangka 
tersebut juga turut mengatur tentang hak - hak dalam konstitusi. Salah satu hak yang terkenal dalam ruanglingkup antara masyarakat dan kepolisian adalah hak Miranda, dalam artianya jika seseorang di tangkap mereka memiliki hak untuk tetap tinggal dan diam, dan apapun yang dia ucapkan bisa di gunakan di pengadilan, serta tersangka berhak di damping oleh penasehat hukum. Penyampaian hak ini harus dihafalkan oleh polisi dan di sampaikan ke pada seorang tersangka. Hak Miranda ini sesuai dengan putusan Mahkamah Agung Miranda $\mathrm{V}^{11}$.

Dari pandangan atas hak ini, terlihat jelas berbeda dengan apa yang dilakukan polisi di Indonesia, yang langsung menangkap saja dan teriak "Jangan Bergerak", tanpa menjelaskan hak umum dari seorang tersangka. Perbuatan yang dilakukan oleh polisi Indonesia ini, seolah menetapka seorang tersangka sebagai 'orang yang bersalah', hal ini tidak sesuai dengan asas yang di anut di Indonesia, yaitu asas Presumption of innocence atau praduga tak bersalah, yang artinya asas dimana seseorang tidak boleh dianggap bersalah atas tindakan yang disangkakan atau di dakwakan kepadanya tanpa ada keputusan pengadilan yang tetap kepadanya ${ }^{12}$.

\section{Kanada}

Kanada adalah sebuah Negara dengan bentuk pemerintahan demokrasi parlementer dan sebuah monarki konstitusional. Negara ini juga menjadi salah satu Negara yang mempunyai keberagaman etnis dan multicultural yang beragam, juga tempat dengan jumlah imigran dengan skala besar. Kanada adalah sebuah Negara maju dengan perekonomian yang cukup besar. ${ }^{13}$

Sebagai Negara maju tentunya kanada memiliki sistem kepolisian layaknya Negaranegara lain. Dalam jurnal "Law Enforcement levels of Policing" dikatakan bahwa polisi adalah komponen yang paling mahal dari sistem peradilan pidana. Bila melihat fungsi dan penerapannya maka dapat dikatakan bahwa memang benar polisi adalah salah satu instrument penting dalam penegakkan hukum, terutama dalam menangani tindak pidana.

Hampir mirip seperti Indonesia, kanada juga mempunyai tingkatan atau bagian pada setiap daerah, sesuai dengan fungsi dan wewenangnya. Kurang lebih ada 4 bagian, yaitu:

\footnotetext{
${ }^{11}$ Op.cit., hlm. 114

${ }^{12}$ Undang - undang Nomor 48 Tahun 2009 tentang Kekuasaan Kehakiman, Pasal 8 ayat (1).

${ }^{13}$ Diakses dari https://ilmupengetahuanumum.com/profil-negara-kanada-canada/ pada 6 Oktober 2019 Pukul 18.00 WIB
} 
Polisi Federal : di Kanada Polisi Federal juga dikenal sebagai "The Royal Canadian Mounted Police" atau RCMP. Dalam tugasnya dapat dikatakan satuan ini adalah satuan yang cukup fleksibel, karena selain tugasnya untuk memberikan layanan investigasi dan perlindungan kepada pemerintah Federal, satuan ini bisa juga berubah menjadi Polisi Provinsi di suatu daerah di kanada. Dalam tugasnya kesatuan ini mempunyai empat mandat yaitu, bertugas di perbatasan, memberantas narkoba dan kejahatan terorganisir, polisi internasional, dan kejahatan financial. RCMP sering menjadi satuan yang diajak kerjasama oleh kepolisian provinsi maupun kota.

Polisi Provinsi : Adalah satuan yang bertugas di daerah pedesaan atau di suatu provinsi tertentu dan juga di daerah yang tidak tergabung dengan Negara bagian.

Polisi kota : salah satu yang unik adalah polisi kota. Polisi di daerah "kota" ini di danai oleh masyarakat yang berada di daerah tersebut, dan yurisdiksinya hanya berlaku di kota itu saja. Dalam tugasnya mereka bertujuan untuk melestarikan perdamaian, agar dapat mencegah tindak pidana. Mereka turut serta dalam penuntutan dan menegakkan kota menurut hukum.

Polisi Aborigin: Hal lain yang cukup menarik adalah keberadaan Polisi yang anggotanya bersuku aborigin. Negara kanada memberikan ruang bagi mereka yang ingin mempunyai pasukan atau anggota asli bangsa sendiri, hal ini melalui perjanjian dengan Polisi Federal. ${ }^{14}$

\section{Polisi di Kanada: Statistik dan Fakta}

Pada 2016 lalu, pengeluaran operasi untuk layanan Polisi di Kanada berjumlah 405 dollar Kanada per kapita. Ontario menjadi provinsi tertinggi dengan 5.000.000.000 dolar Kanada per kapita untuk Polisi di akhir 2017. Seiring dengan jumlah per kapita yang terus naik, jumlah anggota Polisi di Kanada juga meningkat sementara tingkat kejahatan pun menurun selama 1 tahun terakhir.

Selain meningkatnya jumlah Polisi dan pengeluarannya, upah Polisi sendiri juga telah meningkat, dengan rata-rata upah untuk petugas Polisi di Kanada adalah 28,22 Dollar per jam. Selain itu terdapat hal lain yang cukup menarik, yaitu meningkatnya Polisi perempuan di semua jajaran, dan bahkan lebih dari 14 persen posisi perwira senior dipegang oleh perempuan ${ }^{15}$.

\footnotetext{
${ }^{14}$ Correctional Service Canada "Law Enforcement Levels of Policing" 2006 hal.3 dan 5

${ }^{15}$ Diakses dari https://www.statista.com/topics/2833/police-in-canada/ pada 6 Oktober 2019 pukul 19.50 WIB
} 
Berikut ini adalah data mengenai jumlah Polisi dari tahun 2000 sampai 2017

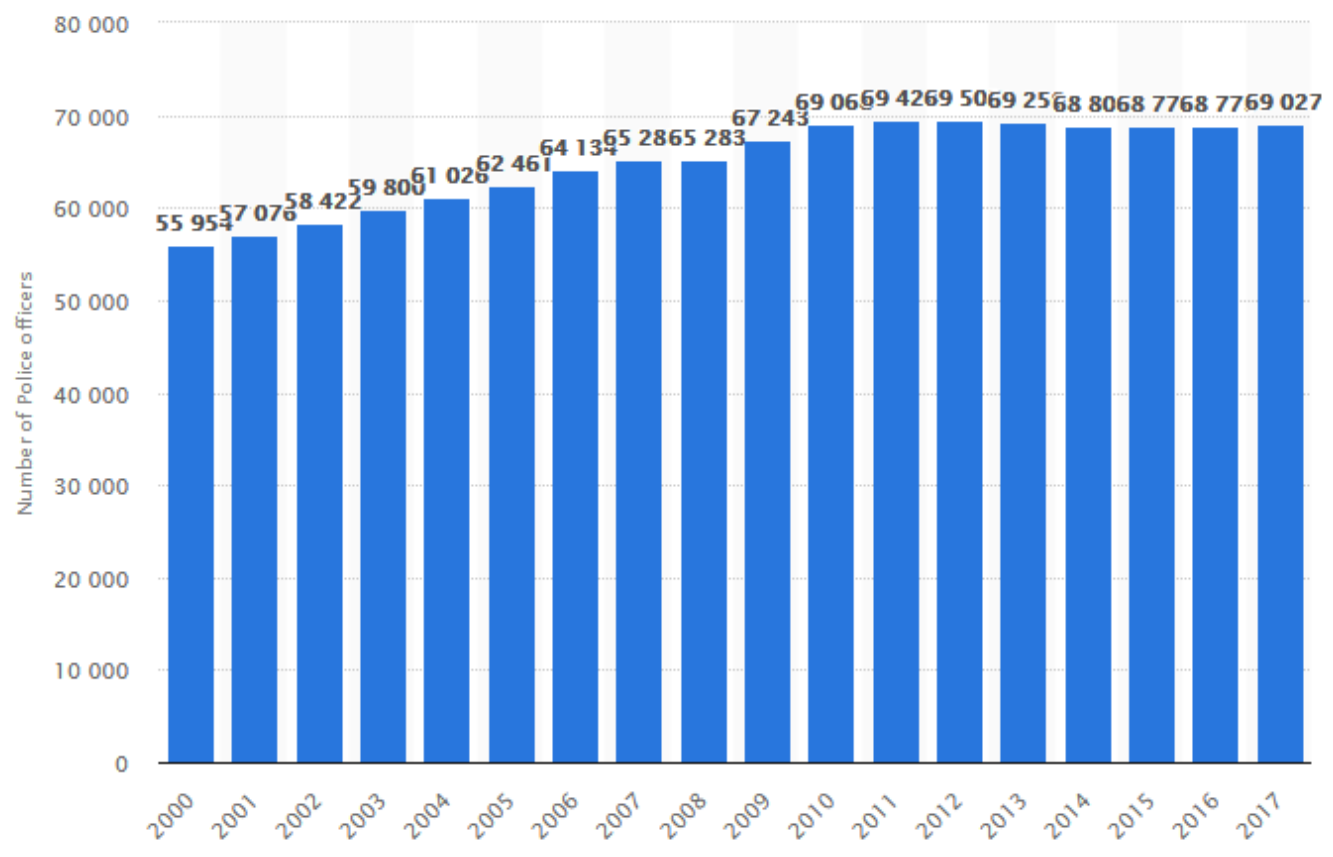

Berdasarkan tabel diatas, dapat dilihat adanya kecenderungan jumlah Polisi yang terus meningkat ${ }^{16}$. Hal ini tentunya menjadi hal yang positif dimana masyarakat mulai memilih untuk mengabdi kepada Negara sebagai penegak hukum, dan tentunya mengurangi peluang untuk seseorang menjadi kriminal.

\section{Mandat komisi dan tantangan}

Dalam menjalani tugas tentu saja Kepolisian memiliki mandat sebagai acuan dalam bertugas. Hal ini tentunya menjadi hal yang biasa dialami oleh setiap Polisi dimanapun berada. Memegang mandat sembari juga menghadapi tantangan dalam setiap tugas. Begitupun Kepolisian Kanada yang setidaknya memiliki tantangan sebagai berikut:

1. Mandat:

a. Merespon keluhan publik dan ulasan (sekitar 2500 keluhan publik dan 225 ulasan banding tahunan)

b. melakukan tinjauan sistemik program RCMP

c. Monitor imparsial insiden serius yang melibatkan RCMP (Independent Observer)

1. Tantangan

\footnotetext{
${ }^{16}$ Diakses dari https://www.statista.com/statistics/436274/number-of-police-officers-in-canada/ pada 6 Oktober 2019 pukul 21.00
} 
a. Kesenjangan dalam ukuran antara program RCMP dan komisi ( sekitar 30.000 pegawai Vs 80)

b. Operasi bersama RCMP: Nasional, Provinsi/Regional terpadu unit di Kanada

c. Komisi tidak memiliki akses yang tidak terkekang ${ }^{17}$

Dalam setiap profesi tentu saja pada prosesnya ada yang tidak puas, yang diutarakan melalui keluhan, baik langsung maupun secara tidak langsung terhadap kinerja suatu lembaga. Kepollisian pun tak luput dari keluhan tentunya, karena sejatinya kita tidak bisa memuaskan semua orang. Lalu bagaimana Kepolisian Kanada menghadapi ini? Ada beberapa tahapan yang dilakukan,yaitu:

1. Diselidiki oleh RCMP

2. Diselidiki oleh Komisi sebagai penyelidikan kepentingan publik

3. Resolusi informal oleh RCMP

4. Sidang Umum oleh Komisi

Langkah-langkah atau tahapan diatas apabila dirasa masih kurang dalam hal penanganan pengaduan oleh RCMP, maka pengadu dapat meminta komisioner untuk memberikan ulasan atau bantuan terhadap pengadu. Lalu di tahap ini RCMP wajib untuk menyediakan semua materi file yang relevan untuk Komisioner, yang mana ulasan itu nantinya akan dilakukan oleh pengacara komisi.

Setelah dilakukan ulasan dan penanganan, maka komisi dapat:

1. Mengirim aduan ataupun keluhan kembali kepada pihak RCMP untuk penyelidikan lebih lanjut.

2. Menyelidiki aduan itu sendiri.

3. Mengadakan sidang umum ${ }^{18}$.

Pada kesimpulan, Komisi akan memutuskan apakah itu puas dengan RCMP yang menangani keluhan atau tidak.

Apabila Puas;

- Temuan yang non merugikan

\footnotetext{
${ }^{17}$ Prof.Adrianus Meliala, Ph.d. Model Pengawasan terhadap Kinerja Kepolisian di berbagai Negara (KOMPOLNAS) (Jakarta 23 Januari 2016) hal.4

${ }^{18}$ Ibid., hal.8
} 
- Komisaris akan memberitahu pengadu, RCMP Komisaris, anggota subyek dan Menteri keselamatan publik.

Apabila tidak puas;

- Komisi akan mengeluarkan laporan interim yang berisi temuan dan rekomendasi untuk RCMP

- RCMP Komisaris akan menanggapi laporan interim

- Komisi akan mengeluarkan laporan akhir yang berisi respon Komisaris RCMP ${ }^{19}$.

Penangananan terhadap keluhan yang didapat dari masyarakat harus dilakukan sebaik mungkin, dan keliahatannya Kanada telah memiliki sistem atau cara yang cukup menarik dalam menangani keluhan. Tentunya apabila angka keluhan dapat ditekan, maka artinya tugas Kepolisian dapat dikatakan semakin baik.

\section{Penutup}

Lembaga Kepolisian di Indonesia tumbuh menjadi lembaga yang sangat penting, terkait tugasnya dalam menangangi kejahatan dan menekan konflik di Indonesia. Dalam menyelesaikan tugasnya banyak hal yang harus diperhatikan oleh Polisi. Tekanan,tantangan menjadi hal yang harus dipikul sembari menjalankan tugas Negara

Pada prakteknya Polisi pun mempunyai aturan atau kode etik mereka sendiri. Hukum kepolisian, adalah salah satu instrument penting dalam menjalankan tugas. Bagi pejabat Kepolisian, penguasaan hukum Kepolisian adalah sebuah keharusan bahkan kebutuhan. Hukum kepolisian diperlukan sebagai acuan normatif dan untuk memberi arahan kepada anggota dalam bertugas. Aturan ini ada karena Kewenangan Polisi adalah mandat dan kekuasaan dari rakyat, untuk itu perlu adanya tanggung jawab.

Hukum Kepolisian bersifat mengatur dan memaksa, memuat baik ketentuan prosedural maupun substantif. Mengatur dalam arti memberi pedoman tantang tata cara pelaksanaan tugas Polisi yang baik. Memaksa artinya aturan yang ada memaksa Polisi untuk melaksanakan tugas dan wewenangnya sesuai ketentuan perundang-undangan, dan bagi yang tidak mematuhinya dikenakan sanksi (Pasal yang mengatur tanggung jawab ${ }^{20}$

\footnotetext{
${ }^{19}$ Ibid., hal.9

${ }^{20}$ Momo Kelana, Hukum Kepolisian,PTIK 1994 hal.2
} 
Polisi mempunyai jatidiri dan keberadaan yang bersifat unik. Tiap Negara memiliki jatidiri Kepolisian yang berbeda-beda, mereka mempunyai ciri khas masing-masing, disamping hal-hal yang bersifat Universal. Ada beberapa istilah yang berkaitan dengan halhal Ihwal kepolisian, yaitu

a. Keamanan

b. Keamanan Nasional

c. Keamanan Negara

d. Keamanan rakyat semesta

e. Keamanan umum dan ketentraman Masyarakat

f. Keamanan dan ketertiban masyarakat

g. Keamanan dalam Negri ${ }^{21}$

Beberapa hal tersebut menjadi hal yang esensial bagi Polisi dalam menjalankan tugasnya. Beberapa perbandingan Kepolisian yang ada diatas sejatinya sebagai gambaran bahwa tiap-tiap Negara mempunyai ciri khas dalam pengelolaan sistem mereka. Walaupun dalam bentuk yang berbeda-beda tiap Negara mempunyai permasalahan atau tujuan yang sama, yaitu memberantas kejahatan dan menegakkan hukum.

Disamping itu hal yang perlu kita perhatikan bukan hanya terhadap pelayanan Kepolisian kepada masyarakat, melainkan juga bagaimana Negara hadir dan memberikan kekuatan pada Kepolisian, yang mana tentunya dengan tanggung jawab yang besar dan tekanan di lapangan maka Negara rasanya wajib untuk memberikan support pada anggota-anggota Kepolisian.

Kesejahteraan anggota Polisi, adalah salah satu hal yang perlu menjadi Concern Negara. Bagaimana kemudian Negara memberikan upah yang cukup dan sesuai, maupun beberapa tunjangan lain yang perlu di berikan. Hal ini kemudian menjadi penting melihat apa yang dilakukan oleh Kepolisian adalah untuk menjamin keamanan dalam Negara, yang mana konflik dan benturan sering terjadi dimana saja dan kapan saja. Jangan sampai seorang Polisi yang sudah meluangkan waktu, tenaga, dan Pikirannya merasa terlantar dan kesulitan dalam menjalani kehidupan sehari-hari. Bila Kanada dengan pemberian Upah yang besar, maka rasanya Indonesia pun bisa dan telah memulai untuk menjamin dan memberikan kesejahteraan bagi anggotanya.

\footnotetext{
${ }^{21}$ Ibid.,hal 5
} 
Terakhir, apabila Negara dan Kepolisian telah bersatu padu untuk menegakkan hukum dan menjaga keamanan, maka elemen terakhir yaitu masyarakat, diharapkan juga mampu untuk bekerja sama dan membantu jalanya tugas kepolisian. Tidak perlu hal yang sulit, apabila masyarakat mematuhi aturan yang ada, dan mengurangi pelanggaran, maka hal tersebut sudah membantu Kepolisian

Selain itu masyarakat bisa bersinergi dengan kepolisian dengan melaporkan kejadian-kejadian yang ada di sekitar, melakukan kegiatan bersama, dan berbagai hal lainnya yang membuat hubungan masyarakat semakin erat dengan Kepolisian. Apabila hal ini sudah berjalan niscaya Kepolisian pun semakin maju karena dicintai masyarakatnya.

\section{Daftar Pustaka}

\section{Buku}

Brewer D. Jhon, dkk.,1996 The Police Public Order And The State, Macmillan press LTD, London

Momo Kelana, 2007, Konsep - konsep Hukum Kepolisian Indonesia, PTIK”Press”, Jakarta Seoebijono, 1995,DWIFUNGSI ABRI, Gadjah Mada University Press, Yogyakarta

Prof.Adrianus Meliala, Ph.d., 2016 Model Pengawasan terhadap Kinerja Kepolisian di berbagai Negara (KOMPOLNAS), Jakarta

Momo Kelana, 1994, Hukum Kepolisian, PTIK”Press", Jakarta

\section{Perundang-undangan}

Undang-undang Dasar Negara Republik Indonesia 1945

Ketetapan MPR nomor VI/MPR/2000

Undang - undang Nomor 2 Tahun 2002 Tentang Kepolisian Negara Indonesia

Undang - undang Nomor 48 Tahun 2009 tentang Kekuasaan Kehakiman

\section{Internet}

https://www.kompasiana.com/efrondp/54f8ffe7a33311fa608b464d/adakah-jabatan-sejeniskapolri-di-amerika-serikat

https://ilmupengetahuanumum.com/profil-negara-kanada-canada/

Correctional Service Canada, 2006 "Law Enforcement Levels of Policing”, Correctional Service Canada

https://www.statista.com/topics/2833/police-in-canada/

https://www.statista.com/statistics/436274/number-of-police-officers-in-canada/ 